\title{
CMR findings in high endurance veteran athletes - a 247 subject study
}

\author{
Viviana Maestrini ${ }^{1 *}$, Ahmed Merghani $^{2}$, Stefania Rosmini ${ }^{3}$, Andrew Cox ${ }^{2}$, Heerajnarain Bulluck ${ }^{3}$, Veronica Culotta ${ }^{3}$, \\ Mun Cheang ${ }^{3}$, Marianna Fontana ${ }^{3}$, Thomas A Treibel ${ }^{3}$, Amna Abdel-Gadir ${ }^{3}$, Sanjay Sharma ${ }^{2}$, James Moon ${ }^{3}$ \\ From 19th Annual SCMR Scientific Sessions \\ Los Angeles, CA, USA. 27-30 January 2016
}

\section{Background}

Athletes demonstrate major adaptative changes in their hearts with high level of exercise. However the long term consequences of endurance training were not completely understood. We aimed to to explore the effect of long term endurance exercise on cardiac morphology and function, and diffuse fibrosis, and assess the significance of any discovered changes (correlation with documented ventricular arrhythmias).

\section{Methods}

Veteran athletes (Vets) were $>40$, did competitive endurance exercise $>10$ years and had done multiple competitions. Controls were healthy volunteers (HV). Demographics, blood pressure, Bloods (hematocrit, renal function, lipids), rest ECG were collected. CMR at $1.5 \mathrm{~T}$ with T1 mapping (ShMOLLI and MOLLI) was performed using extracellular volume (ECV) quantification. The intracellular volume (1-ECV) and total cell volume $(\mathrm{ICV} \times \mathrm{LVMass} / 1.05)$ were derived. Vets also had a 24hour Holter. Scar was defined on LGE as "Overt" - in the compacted LV myocardium (ischaemic or nonischemic pattern) and not limited to the RV insertion points or "minor" (RV scar, RV insertion point scar or papilliary muscle scar).

\section{Results}

247 subjects were recruited: 158 Vet ( $71 \%$ male, mean \pm SD age:55 \pm 8 ys) and $89 \mathrm{HV}$ (53\% male, mean age $50 \pm$ $13 \mathrm{ys}$ ). Vets (male and female) demonstrated increased $\mathrm{LV}$ volumes, mass and atria size, with no difference in ejection fraction.

${ }^{1}$ Cardiology, La Sapienza, Rome, Italy

Full list of author information is available at the end of the article
LGE: Healthy volunteers had no overt scar but $10 \%$ had minor scar - all of which was inferior RV insertion point. Vets had overt myocardial scar in $11.4 \%$. This was $56 \%$ non-ischemic, $33 \%$ ischemic, $11 \%$ both. This was mainly males $(15.2 \%$ vs $2.2 \%, \mathrm{p}=0.025)$. In addition, minor scar was high prevalence - inferior RV insertion point $19.6 \%$, papillary muscles $27.8 \%$, and right ventricle trabeculae $10.1 \%$ (Figure 1). These significant differences persisted when age and sex matched comparisons with HVs was made.

Overt LGE was significantly associated with non sustained ventricular tachycardia $(\mathrm{OR}=5.4,95 \% \mathrm{CI} 1.2$ 24.9, $\mathrm{p}=0.030$ ).

Native T1 and ECV (drawn away from scar) were significantly LOWER in Vets. This was the same on MOLLI and ShMOLLI. MOLLI: native T1 $988 \pm 23$ vs $1018 \pm 36, \mathrm{p}<0.001$; ECV $0.26 \pm 0.024$ vs $0.27 \pm 0.03$, $\mathrm{p}=0.002$; ShMOLLI: native T1 $929 \pm 26$ vs $952 \pm 29$ ms, p < 0.001; ECV $0.26 \pm 0.029$ vs $0.28 \pm 0.028, \mathrm{p}<$ $0.00)$. The total cell volume were higher in Vets $(104 \pm$ 25 vs $85 \pm 24 \mathrm{ml}, \mathrm{p}<0.001)$, and specifically higher in the group with LV mass to volume ratio $>1 \quad(105 \pm 22$ vs $82 \pm 23 \mathrm{ml}, \mathrm{p}=0.002$ ) (Figure 2 ). The total cell volume correlatee with MWT $(r=0.74 \mathrm{p}<0.001)$ and LA area $(\mathrm{r}=0.48 \mathrm{p}<0.001)$.

\section{Conclusions}

Veteran athletes have increased LV and atrial size and increased LV mass. The LVH in veterans has a lower ECV and T1 than health - suggesting hypertrophy (away from scar) is cellular rather than interstitial. Compared to age/sex matched controls, there is significant overt (11\%), and minor (25\%) scarring. Overt scar was highly associated with NSVT.

The impression therefore is that sustained athleticism causes scarring which is detrimental. 


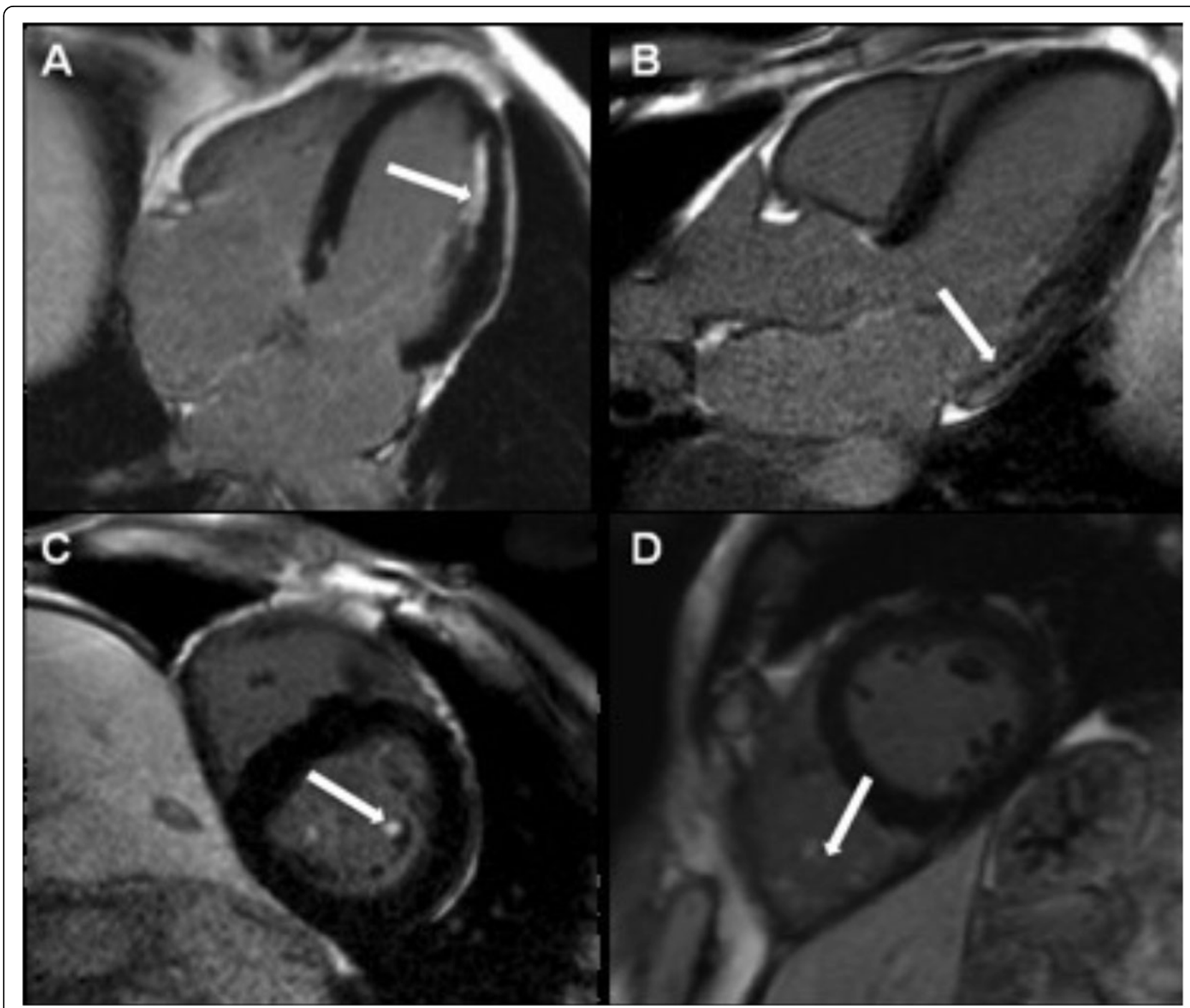

Figure 1 Examples of different LGE pattern in veteran athletes: A) overt ischemic, B) overt non ischemic, c) minor, involving the papillary muscles or 4) minor, RV trabeculae.

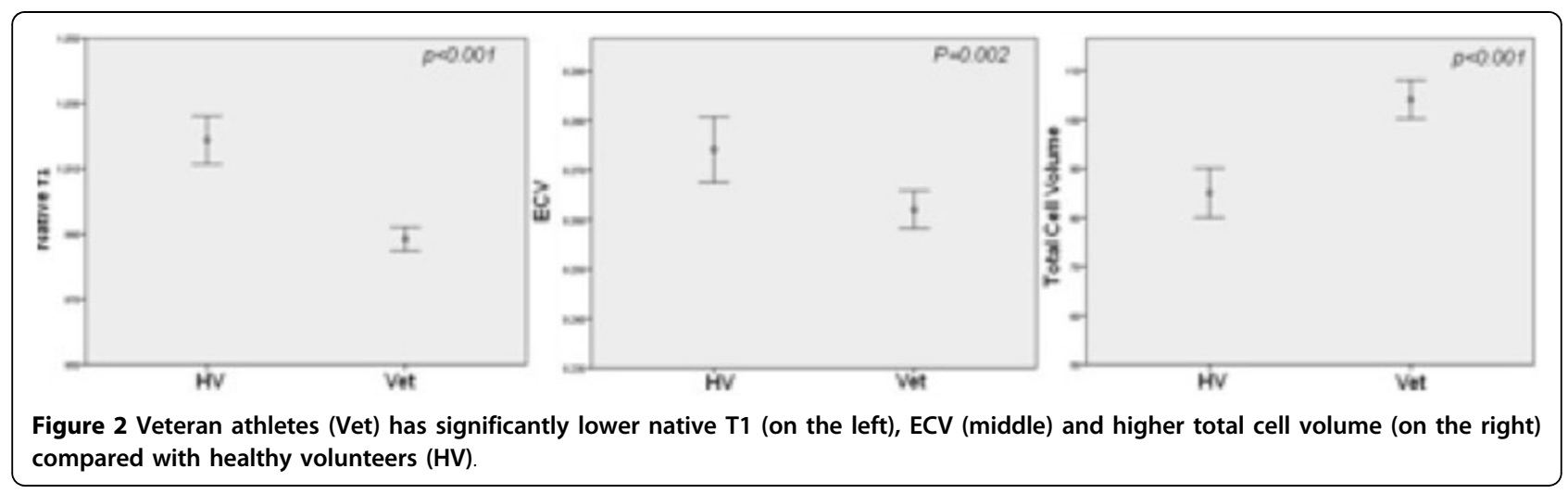




\title{
Authors' details
}

${ }^{1}$ Cardiology, La Sapienza, Rome, Italy. ${ }^{2}$ St George Hospital, London, UK. ${ }^{3}$ Barts Heart Hospital, London, UK.

Published: 27 January 2016

\author{
doi:10.1186/1532-429X-18-S1-038 \\ Cite this article as: Maestrini et al:: CMR findings in high endurance \\ veteran athletes - a 247 subject study. Journal of Cardiovascular Magnetic \\ Resonance 2016 18(Suppl 1):O38.
}

Submit your next manuscript to BioMed Central and take full advantage of:

- Convenient online submission

- Thorough peer review

- No space constraints or color figure charges

- Immediate publication on acceptance

- Inclusion in PubMed, CAS, Scopus and Google Scholar

- Research which is freely available for redistribution

Submit your manuscript at www.biomedcentral.com/submit 